\title{
Ericaceae do Parque Nacional do Itatiaia, RJ, Brasil ${ }^{1}$
}

\author{
Viviane Mezabarba ${ }^{2}$, Marcelo Dias Machado Vianna Filho' ${ }^{2}$, Rafael Augusto Xavier Borges ${ }^{2} \mathrm{e}$ \\ Vidal de Freitas Mansano ${ }^{2,3}$
}

Recebido: 26.04.2010; aceito: 13.01.2012

\begin{abstract}
Ericaceae from Parque Nacional do Itatiaia, Rio de Janeiro State, Brazil). This work presents the floristic survey of Ericaceae from Parque Nacional do Itatiaia, located in the States of Rio de Janeiro and Minas Gerais, Southeastern Brazil. After fieldwork, bibliographic revision, and analysis of herbarium material, 14 species were identified in three genera: Agarista (4), Gaultheria (5), and Gaylussacia (5). Identification key, descriptions, illustrations, and comments on geographical distribution are presented.
\end{abstract}

Key words: Atlantic Forest, biodiversity, flora, highland fields, taxonomy

RESUMO - (Ericaceae do Parque Nacional do Itatiaia, RJ, Brasil). O presente trabalho compreende o levantamento florístico da família Ericaceae no Parque Nacional do Itatiaia, localizado nos Estados do Rio de Janeiro e Minas Gerais, Sudeste do Brasil. Após a realização de coletas e observações de campo, levantamento bibliográfico e consulta a herbários, foram registradas 14 espécies subordinadas a três gêneros: Agarista (4), Gaultheria (5) e Gaylussacia (5). São apresentados chave de identificação, descrições morfológicas, ilustrações e comentários sobre a distribuição geográfica das espécies.

Palavras-chave: biodiversidade, campo de altitude, flora, Mata Atlântica, taxonomia

\section{Introdução}

A família Ericaceae Juss. é composta por 124 gêneros e 4.100 espécies (Stevens 2001, Judd et al. 2004, 2009), sendo que no Brasil é registrada a ocorrência de 12 gêneros e 100 espécies (Souza \& Lorenzi 2008, Kinoshita et al. 2010). Apresenta espécies cosmopolitas, que são comuns em regiões tropicais montanas da África do Sul, Austrália, leste da Ásia e leste da América do Norte (Stevens 2001, Judd et al. 2004, 2009). No Brasil, ocorrem principalmente nos campos rupestres da Cadeia do Espinhaço e campos de altitude das regiões Sul e Sudeste (Souza \& Lorenzi 2008).

A família está inserida na ordem Ericales e tem como grupo-irmão a família Cyrillaceae (Kron et al. 1996, 1999, Stevens 2001). A circunscrição atual de Ericaceae compreende as tribos Empretreae D. Don, Epacrideae Dumort., Monotropeae Dumort., Pyroleae Dumort. e Vaccinieae Rchb. (Kron et al. 1996, 1999, Stevens 2001, Judd et al. 2004, 2009).
As espécies de Ericaceae são caracterizadas, de forma geral, pelo hábito arbustivo ou arbóreo; folhas simples, alternas e espiraladas, algumas vezes subopostas ou verticiladas; inflorescências variadas, axilares ou terminais; flores hermafroditas, diclamídeas, actinomorfas ou zigomorfas, geralmente pêndulas; cálice gamossépalo, muitas vezes persistente no fruto; corola gamopétala, urceolada a campanulada; androceu diplo ou isostêmone, estames geralmente livres ou ligeiramente epipétalos, filetes geniculados ou subulados, anteras bífidas, poricidas, pólen em tétrades; ovário súpero ou ínfero, com 4-5 lóculos multiovulados ou 10 lóculos uniovulados, estilete terminal inteiro, estigma capitado; fruto cápsula loculicida, baga ou nuculânio e sementes com endosperma carnoso (Kron et al. 1999, Stevens 2001, Judd et al. 2004, 2009).

O primeiro estudo sobre as espécies de Ericaceae do Brasil foi apresentado por Meissner (1863) na Flora Brasiliensis, que reconheceu 70 binômios em 12 gêneros e foi considerado o principal levantamento

1. Parte da Iniciação Científica da primeira Autora no Programa Mata Atlântica, Instituto de Pesquisas Jardim Botânico do Rio de Janeiro

2. Instituto de Pesquisas Jardim Botânico do Rio de Janeiro, DIPEQ, Rua Pacheco Leão 915, 22460-030 Rio de Janeiro, RJ, Brasil

3. Autor para correspondência: vidalmansano@gmail.com 
para a família no Brasil até a revisão desenvolvida por Kinoshita (1979), que reconheceu 20 gêneros e 90 espécies para a família. Marques (1975) apresentou as espécies de Ericaceae de Santa Catarina, enquanto mais recentemente, Silva \& Cervi $(1999,2006)$ descreveram as espécies nativas no Estado do Paraná. Romão \& Castro (2003) estudaram as Ericaceae do Parque Nacional do Caparaó, MG, e encontraram três gêneros e seis espécies para a área. Outro estudo feito por Romão et al. (2004) para a flora do Parque Estadual de Grão-Mogol, MG, apresentou dois gêneros e cinco espécies da família para a área, porém pouco similares com a flora de Itatiaia. Mesmo com esses estudos, os dados sobre táxons brasileiros de Ericaceae são escassos frente à grande diversidade neotropical da família em ambientes montanos (Luteyn 1992). Kinoshita \& Romão (2010) publicaram a listagem de Ericaceae ocorrentes no Brasil considerando 11 gêneros, 96 espécies e 27 variedades e, em 2012, os mesmos autores apresentaram o tratamento taxonômico das espécies ocorrentes no Estado de São Paulo (Kinoshita \& Romão 2012).

Para a área do Parque Nacional do Itatiaia (PNI), o primeiro estudo em que houve menção da listagem das espécies da família Ericaceae, dentre outras famílias, foi feito por Brade (1956), o qual citou para a região do PNI, 18 binômios agrupados em três gêneros, Leucothoe D. Don (= Agarista D. Don ex G. Don), Gaultheria L. e Gaylussacia Kunth.

Este trabalho tem como objetivos o levantamento e a identificação das espécies de Ericaceae do PNI, a confecção de chave de identificação, e a apresentação de descrições, ilustrações e dados sobre o ambiente preferencial dessas espécies.

\section{Material e métodos}

Área de estudo - O Parque Nacional do Itatiaia (PNI) está localizado na região Sudeste do Brasil, mais especificamente entre o sudoeste do Estado do Rio de Janeiro e o Sul do de Minas Gerais $\left(22^{\circ} 30^{\prime}-22^{\circ} 33^{\prime} \mathrm{S}\right.$ e $\left.42^{\circ} 15^{\prime}-42^{\circ} 19^{\prime} \mathrm{W}\right)$, abrangendo área de cerca de 30.000 ha (figura 1).

O maciço do Itatiaia é um dos grandes afloramentos rochosos do mundo, constituído por rochas do tipo Nefelino e por massas de Sienito (Lamego 1935, Segadas-Vianna \& Dau 1965). Dentre as bacias hidrográficas que se destacam na região estão as do rio Paraíba do Sul e do rio Paraná (Brade 1956, MA-IBDF \& FBCN 1982). O Parque é caracterizado por relevo de elevações rochosas que variam de 650 a $2.780 \mathrm{~m}$, conferindo à área diferentes tipos de fitofisionomias: Floresta Estacional Semidecidual Montana na vertente continental do Parque, acima dos $500 \mathrm{~m}$ de altitude; Floresta Ombrófila Densa Montana, nas áreas com altitude entre 650 e 1.500 m; Floresta Ombrófila Mista Montana em altitudes de cerca de $1.200 \mathrm{~m}$; Floresta Ombrófila Densa Alto Montana, acima de $1.500 \mathrm{~m}$ de altitude e Campos de Altitude, na parte mais elevada do planalto, acima de $1.600 \mathrm{~m}$ de altitude (Morim 2002).

Coleta e análise do material - Foram realizadas coletas mensais, com duração de cinco dias, associadas à revisão dos espécimes depositados em herbários. Foram observadas as áreas de distribuição das espécies e coletadas informações sobre os táxons, na flora local. Registraram-se as épocas de floração e frutificação e localidades específicas na área em estudo. O material coletado foi depositado no herbário RB, além de serem consultados os herbários GUA, HB, R, RB, SP e SPF, siglas de acordo com Holmgren et al. (1990).

\section{Resultados e Discussão}

No trabalho foram encontradas 14 espécies subordinadas a três gêneros: quatro espécies pertencentes a Agarista [A. eucalyptoides (Cham. \& Schltdl.) G. Don, A. hispidula (DC.) Hook. ex Nied., A. oleifolia var. oleifolia G. Don e A. uleana (Sleumer) Judd], caracterizadas por apresentarem filetes filiformes e geniculados, anteras com o ápice truncado e fruto capsular; cinco espécies de Gaultheria [Gaultheria bradeana Sleumer, G. eriophylla (Pers.) Sleumer ex Burtt., G. myrtilloides Cham. \& Schltdl., G. itatiaiae Wawra, G. serrata (Vell.) Sleumer ex Kin.-Gouv.], caracterizadas pelos filetes subulados e anteras com o ápice bidentado ou biaristado, ovário súpero e fruto do tipo cápsula; e cinco espécies de Gaylussacia [Gaylussacia amoena Cham., G. brasiliensis var. brasiliensis (Spreng.) Meisn., G. chamissonis Meisn., G. decipiens Cham. e G. fasciculata Gardner], caracterizadas pelo ovário ínfero, aderido à parede do receptáculo e fruto do tipo nuculânio. As espécies estudadas ocorrem preferencialmente nos campos de altitude, sendo também encontradas em áreas de floresta montana.

Dos 18 binômios apresentados por Brade (1956) para o PNI, apenas 15 espécies são aceitas atualmente: Agarista hispidula (DC.) Hook. ex 
Nied., A. eucalyptoides (Cham. \& Schltdl.) G. Don, A. oleifolia var. oleifolia G. Don, Gaultheria bradeana Sleumer, G. eriophylla (Pers.) Sleumer ex Burtt., G. itatiaiae Wawra, G. serrata (Vell.) Sleumer ex Kin.-Gouv., Gaylussacia amoena Cham., G. chamissonis Meisn. e G. fasciculata Gardner. As espécies tratadas como Leucothoe foram transferidas para Agarista (ver Luteyn 1995), sendo que foram também incluídos na lista do autor dois nomina nuda: L. argyrodesma Sleumer e L. multiflora var. eucalyphridis G. Don.

Apesar de citadas para o PNI por Brade (1956), não foram encontrados registros em campo ou em materiais de herbário de Gaylussacia octosperma Gardner, G. pseudogaultheria Cham. \& Schltdl., G. riedelii Meisn. e G. vitis-idaea Mart.

Gaultheria bradeana, G. eliptica Cham. $(=$ G. serrata), G. itatiaiae, G. glaziovii (= G. itatiaiae), Leucothoe itatiaiae Wawra $(=G$. itatiaiae) e L. rivularis Sleumer (= A. oleifolia var. oleifolia) foram consideradas endêmicas do Parque (Brade 1956). No entanto, constatou-se no presente estudo que o PNI não apresenta espécies endêmicas de Ericaceae, apesar de ser a localidade típica de Gaultheria bradeana e G. itatiaiae. Verificou-se que Gaultheria eriophylla var. eriophylla apresenta distribuição disjunta com a região andina (Peru e Bolívia), o que ressalta a importância de estudos biogeográficos mais detalhados.

Em inventários das Ericaceae para o Estado de Minas Gerais, no Parque Nacional do Caparaó, foram encontrados três gêneros e seis espécies (Romão \& Souza 2003), sendo que Agarista oleifolia, Gaultheria eriophylla e G. serrata ocorrem também no PNI. Para a flora do Parque Estadual de Grão-Mogol, foram registrados dois gêneros e cinco espécies (Romão et al. 2004), não havendo nenhum táxon em comum com o PNI. No inventário para o Parque Nacional da Serra do Cipó (Romão 2003) foram registrados dois gêneros e 26 espécies, sendo que apenas A. eucalyptoides e A. glaberrima ocorrem em comum com o PNI.

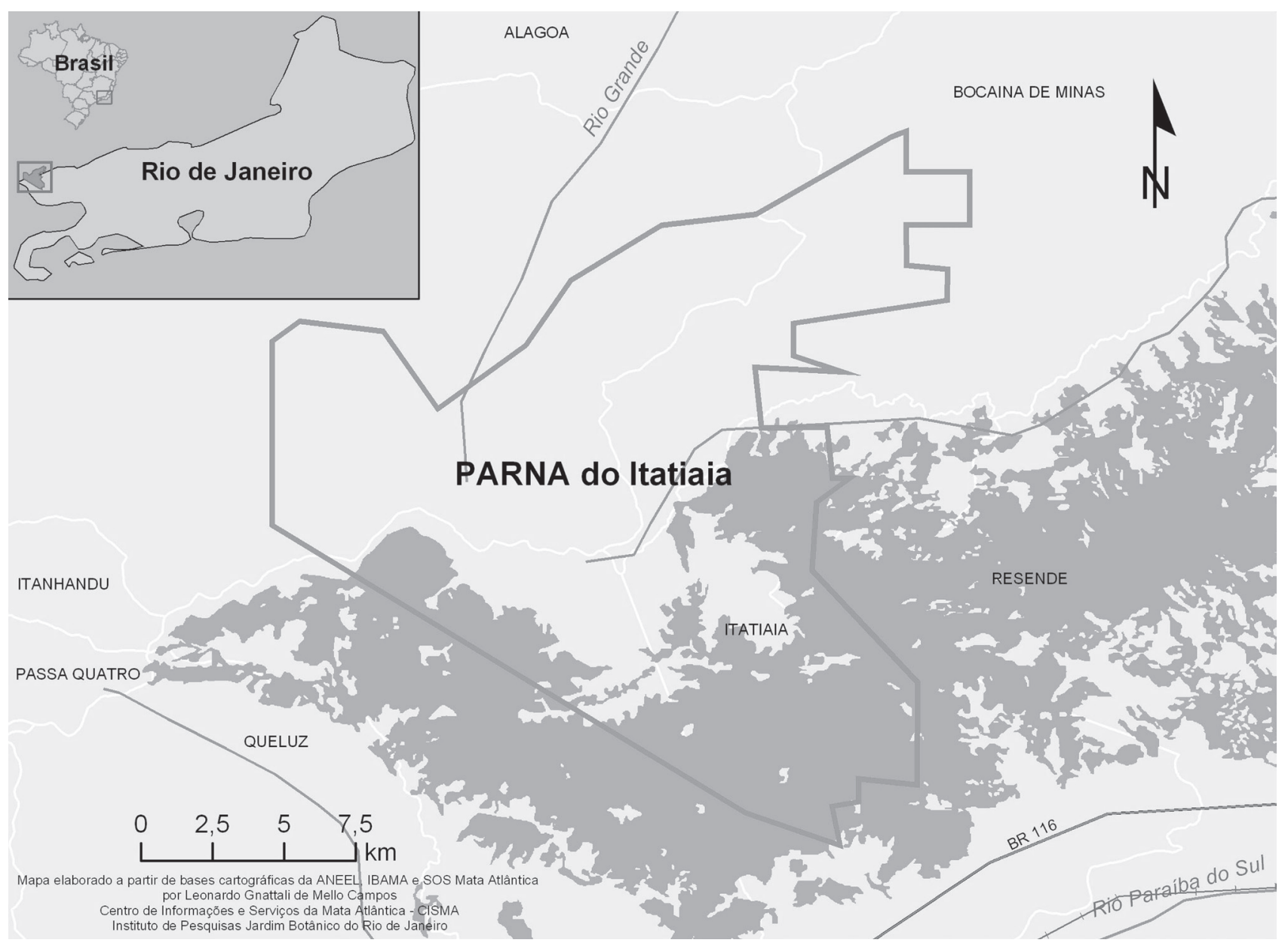

Figura 1. Mapa de localização do Parque Nacional do Itatiaia, RJ, Brasil.

Figure 1. Map with the location of Parque Nacional do Itatiaia, Rio de Janeiro State, Brazil. 
Gaylussacia apresenta maior número de espécies nas áreas de campo de altitude e campos rupestres analisadas (Romão 2003, Romão \& Souza 2003, Romão et al. 2004), reflexo da maior diversidade do grupo no Brasil (Kinoshita \& Romão 2010).
Em relação às áreas serranas do Estado de Minas Gerais, o PNI possui um maior número de espécies de Ericaceae (Romão \& Castro 2003, Romão et al. 2004), exceto em comparação com a Serra do Cipó (Romão 2003).

Chave para identificação dos táxons de Ericaceae ocorrentes no Parque Nacional do Itatiaia

1. Ovário ínfero, aderido à parede do receptáculo; fruto nuculânio (Gaylussacia)

2. Corola largamente campanulada

3. Ramos extremamente ramificados; râmulos pubérulos com tricomas curtos, parecendo cerdas

3. Ramos corimboso-ramificados; râmulos tomentosos a hirsutos G. decipiens

2. Corola cilíndrica ou cilíndrico-urceolada, nunca campanulada

4. Corola tubulosa, com glândulas estipitadas e tricomas subcerdosos longos G. chamissonis

4. Corola cilíndrico-urceolada, sem glândulas estipitadas, com tricomas subcerdosos longos

5. Face abaxial da lâmina com tricomas glandulares conspícuos G. fasciculata

5. Face abaxial da lâmina glabrescente a glabra G. brasiliensis var. brasiliensis

1. Ovário súpero, não aderido à parede do receptáculo; fruto cápsula

6. Filetes filiformes, geniculados; anteras truncadas no ápice (Agarista)

7. Lâminas foliares com até $2 \mathrm{~cm}$ compr., cordadas na base A. hispidula

7. Lâminas foliares com mais de $2 \mathrm{~cm}$ compr., atenuadas a arredondadas na base

8. Estípulas ausentes A. eucalyptoides

8. Estípulas presentes

9. Bractéolas inseridas na base do pedicelo; filetes ca. $5 \mathrm{~mm}$ compr.; tricomas glandulares; estilete ca. $5 \mathrm{~mm}$ compr., tricomas simples na base A. uleana

9. Bractéolas inseridas na metade do comprimento do pedicelo; filetes ca. $6 \mathrm{~mm}$ compr., tricomas simples; estilete ca. $7 \mathrm{~mm}$ compr., glabro A. oleifolia var. oleifolia

6. Filetes subulados, não geniculados; anteras bidentadas ou biaristadas no ápice (Gaultheria)

10. Flores solitárias; corola nitidamente campanulada; ovário glabro

11. Lâmina subcoriácea, ápice mucronado; tubo da corola ca. $2 \mathrm{~mm}$ compr. G. bradeana

11. Lâmina coriácea, ápice não mucronado; tubo da corola 3-3,5 mm compr G. myrtiolloides

10. Flores reunidas em inflorescência; corola urceolada ou cilíndrico-urceolada; ovário revestido por indumento

12. Pecíolo 1-2 mm compr; anteras sem apículos; corola cilíndrico-urceolada G. itatiaiae

12. Pecíolo 4-7 mm compr.; anteras com apículos notáveis; corola urceolada

13. Margem foliar inteira, revoluta; raque da inflorescência ferrugíneo-vilosa, com raros tricomas glandulares G. eriophylla var. eriophylla

13. Margem foliar moderadamente crenada a serrada, não revoluta; raque da inflorescência sem indumento ferrugíneo, pubescente a tomentosa, com tricomas glandulares

G. serrata var. serrata

\section{Agarista D. Don ex G. Don}

Arbusto ou subarbusto, ramos cilíndricos. Folhas com margem inteira, frequentemente revoluta, com glândulas no ápice. Flores dispostas em racemos, axilares ou subterminais; pedicelo apresentando uma bráctea aderida a sua base e, geralmente, 2 bractéolas acima desta; cálice rotáceo a campanulado, 5-lobado; corola alva a avermelhada, urceolada, 5-lobada; 10 estames, homodínamos, persistentes; filetes filiformes, geniculados próximo à antera, anteras ovais a elípticas, superfície lisa a papilosa, ápice truncado; ovário súpero, não aderido a parede do receptáculo, 5-locular, 5-ovulado; estilete cilíndrico, reto; estigma truncado. Fruto cápsula.

O gênero Agarista apresenta 30 espécies e distribui-se desde os Estados Unidos até o Sul da América do Sul, especialmente no Sudeste do Brasil (Stevens et al. 2004). 
1.1. Agarista eucalyptoides (Cham. \& Schltdl.) G. Don, Gen. Hist. 3: 837. 1826.

Figura 2 g-1

Arbusto ou subarbusto, ca. $5 \mathrm{~m}$ alt., ramos glabrescentes, tricomas dispersos, raramente podendo apresentar glândulas dispersas. Estípulas ausentes. Pecíolo 2,2-1,5 cm compr., tricomas simples, às vezes glandulares; lâminas ovadas, concolores, oblongas a elípticas, 7-4,7 × 2,2-1,5 cm, ápice acuminado a curtamente mucronado, base arredondada, geralmente assimétrica, ambas as faces com tricomas esparsos, glabrescente, margem levemente revoluta, às vezes com alguns tricomas. Inflorescência axilar, indumento ferrugíneo com tricomas simples, às vezes também com tricomas glandulares no pedúnculo e na raque. Flores com pedicelo 3-6 mm compr., com tricomas simples, ferrugíneos, ocasionalmente com tricomas glandulares, bráctea 1 , lanceolada, $3 \times 1 \mathrm{~mm}$, ambas as faces com bractéolas lanceoladas, inseridas acima do pedicelo, $1,5 \times 2 \mathrm{~mm}$, com indumento ferrugíneo, margem ciliada, tricomas simples e glandulares; cálice campanulado, 1,5-2 mm compr., ápice triangular, internamente glabrescente, com tricomas simples, ferrugíneos, externamente glabro, margem ciliada, tricomas simples, ferrugíneos, corola alva, lobos $1 \mathrm{~mm}$ compr., glabra, serícea apenas na face externa, $3 \mathrm{~mm}$ compr. Estames ca. $5 \mathrm{~mm}$ compr., filetes ca. $3 \mathrm{~mm}$ compr., tomentoso-ferrugíneos, tricomas glandulares diminutos, anteras ca. 1,5 mm compr.; ovário glabro, estilete $4 \mathrm{~mm}$ compr., glabro. Cápsula globosa, $5 \mathrm{~mm}$ diâm., glabra.

Esta espécie está amplamente distribuída, ocorrendo no Brasil e no Uruguai (Luthein 1995). No Brasil, distribui-se desde o Estado da Bahia até o Rio Grande do Sul, havendo maior concentração no Sudeste do Brasil, principalmente no Parque Nacional do Caparaó, em Minas Gerais (Kinoshita 1979). No Estado do Rio de Janeiro é encontrada apenas no PNI, em campos de altitudes acima de $2.000 \mathrm{~m}$. No Parque, é encontrada fértil entre setembro e novembro.

Material selecionado: BRASIL. RIo DE JANEIRo: Itatiaia, Parque Nacional do Itatiaia. Campo de altitude, IX-1934, A.C. Brade 14086 (RB); Planalto, XI-1918, C. Porto 826 (RB).

Material adicional examinado: BRASIL. MinAs Gerais: Serra da Moeda, BR 3, 17-XI-1965, A.P. Duarte 8897 (RB).
1.2. Agarista hispidula (DC.) Hook. f. ex Nied., Bot. Jahrb. Syst. 11: 236. 1889.

Figura $2 \mathrm{a}-\mathrm{f}$

Arbusto ou subarbusto, ca. $1 \mathrm{~m}$ alt., ramos cilíndricos, pubérulos, tricomas glandulares dispersos. Estípulas ausentes; pecíolo ca. $5 \mathrm{~mm}$ compr., tricomas simples, curtos, ocasionalmente tricomas glandulares; lâmina concolor, subcoriácea, ovada, 1,3-1,5 × 0,4-0,6 cm, ápice acuminado a mucronado, base cordada, ambas as faces com tricomas simples ou glandulares adensados na nervura central, proeminente na face abaxial, margem revoluta. Inflorescência axilar, raque pubescente. Flores com pedicelo ca. $4 \mathrm{~mm}$ compr., brácteas e bractéolas linear-lanceoladas, bractéolas inseridas acima do pedicelo, $1 \mathrm{~mm}$ compr., internamente glabrescentes, externamente denso-pubescentes; cálice campanulado com ápice agudo, $2 \times 3 \mathrm{~mm}$, face interna e externa pubescente, com tricomas simples, às vezes também com tricomas glandulares, corola avermelhada ou rósea, lobos ca. 1,2 $\mathrm{mm}$ compr., dorso ca. $8,5 \mathrm{~mm}$ compr., inteiramente pubescente, face externa com tricomas glandulares. Estames ca. $7 \mathrm{~mm}$ compr., filetes ca. $6 \mathrm{~mm}$ compr., apresentando tricomas simples e glandulares; anteras 1-1,5 mm compr. Ovário $1 \mathrm{~mm}$ compr., densamente pubescente, estilete $6 \mathrm{~mm}$ compr., levemente dilatado no ápice, piloso na base. Cápsula depresso-globosa, 4-5 mm diâm., esparsamente pilosa, glabrescente.

Espécie endêmica do Sudeste do Brasil, ocorre em áreas serranas de Minas Gerais e do Rio de Janeiro (Kinoshita 1979). No PNI, a área de ocorrência de A. hispidula concentra-se nos trechos do planalto mais próximo ao trecho conhecido como Prateleiras, sendo comum na beira das trilhas. Coletada fértil entre fevereiro e dezembro.

Material selecionado: BRASIL. Rio DE JANEIRO: Itatiaia, Parque Nacional do Itatiaia, Abrigo Rebouças, 3-XII-1964, M.C. Vianna 184 (GUA); Base da Agulhas Negras, XI-1938, F. Markgraf \& A.C. Brade 3727 (RB); Caminho para as prateleiras, 27-IX-1980, M.B. Casari 364 (GUA); Planalto, 6-XI-1976, G. Martinelli 1079 (RB); Planalto trilha para as prateleiras, 26-IX-1995, S.J. Silva Neto et al. 834 (RB); Prateleiras, 12-IX-1975, A.M. Caminil 20 (RB); Rebouças, 9-XI-1969, J.P.P. Carauta 926 (GUA); Serra do Itatiaia, 17-V-1902, P. Dusén 52 (R); Serra do Itatiaia, em morros na serra, II-1977, E. Ule 188 (R); Trilha do Abrigo Rebouças para o abrigo Massenas, 17-III-1995, J.M.A. Braga et al. 2549 (RB). 


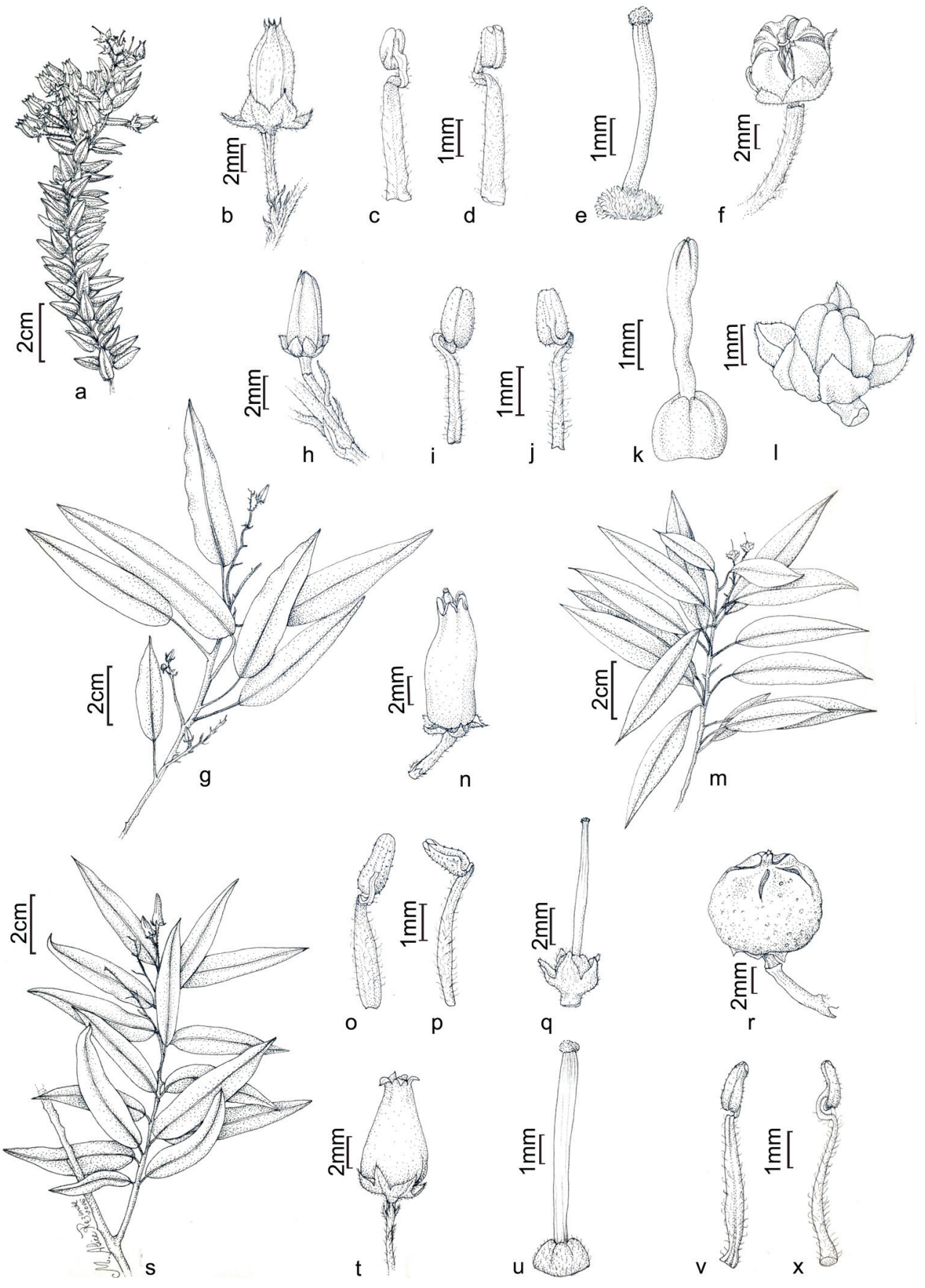

Figura 2. a-f. Agarista hispidula (DC.) Hook. f. ex Nied. a. Ramo florífero. b. Flor em botão. c. Estame em vista dorsal. d. Estame em vista ventral. e. Gineceu (S.J. Silva Neto 1180). f. Fruto (J.M.A. Braga 2549). g-1. Agarista eucalyptoides (Cham. \& Schltd1.) G. Don. g. Ramo florífero. h. Flor em botão. i. Estame em vista ventral. j. Estame em vista dorsal. k. Gineceu. 1. Fruto (A.P. Duarte 8897). m-r. Agarista uleana (Sleumer) Judd. m. Ramo florífero. n. Flor em botão. o. Estame em vista dorsal. p. Estame em vista ventral. q. Gineceu (A.P. Duarte 5302). r. Fruto. s-x. Agarista oleifolia (Cham.) G. Don var. oleifolia. s. Ramo florífero. t. Flor. u. Gineceu, v. Estame em vista ventral. x. Estame em vista lateral (F. Markgraf 21264).

Figure 2. a-f. Agarista hispidula (DC.) Hook. f. ex Nied. a. Flowering branch. b. Flower bud. c. Stamen, ventral view. d. Stamen, dorsal view. e. Gynoecium (S.J. Silva Neto 1180). f. Fruit (J.M.A. Braga 2549). g-1. Agarista eucalyptoides (Cham. \& Schltdl.) G. Don. g. Flowering branch. h. Flower bud. i. Stamen, dorsal view. j. Stamen, ventral view. 1. Gynoecium. f. Fruit (A.P. Duarte 8897). m-r. Agarista uleana (Sleumer) Judd. m. Flowering branch. n. Flower bud. o. Stamen, dorsal view. p. Stamen, ventral view. q. Gynoecium (A.P. Duarte 5302). r. Fruit. s-x. Agarista oleifolia (Cham.) G. Don var. oleifolia. s. Flowering branch. t. Flower. u. Gynoecium, v. Stamen, ventral view. x. Stamen, lateral view (F. Markgraf 21264). 
1.3. Agarista oleifolia (Cham.) G. Don var. oleifolia, Gen. Hist. 3: 838. 1834.

Figura $2 \mathrm{~s}-\mathrm{x}$

Arbusto ou subarbusto, 0,5-2,5 m alt., ramos glabros e râmulos pubérulos, ocasionalmente com tricomas glandulares. Estípulas $1 \mathrm{~mm}$ compr.; pecíolo 4-5 mm compr., pubérulo, ocasionalmente com tricomas glandulares, lâmina subcoriácea, concolor, elíptico-lanceolada, 3,7-5,6 × 1-1,4 cm, ápice mucronado a apiculado, base arredondada, assimétrica, face adaxial pubérula, principalmente na nervura central, raramente em todo o limbo, ocasionalmente com tricomas glandulares, face abaxial pubérula principalmente na nervura central, fortemente proeminente, margem revoluta, tricomas glandulares esparsos. Inflorescência axilar pubescente, tricomas glandulares. Flores com pedicelo de 5-6 mm compr., tricomas glandulares, bráctea e bractéolas lanceoladas, inseridas na metade do pedicelo, 1-2 $\times 0,5 \mathrm{~mm}$, ambas as faces pubescentes, margem ciliada; cálice campanulado, 1-3 mm compr., ápice triangular, pubescente em ambas as faces, principalmente próximo ao ápice e à margem; corola alva, glabra às vezes com tricomas simples interna ou externamente; estames 5-8 $\mathrm{mm}$ compr., filetes ca. $6 \mathrm{~mm}$ compr., tricomas simples, levemente adpressos, anteras $1 \mathrm{~mm}$ compr.; ovário pubescente, principalmente no ápice, estilete ca. $7 \mathrm{~mm}$ compr., glabro. Fruto não visto.

A espécie está amplamente distribuída no Brasil, ocorrendo desde o Estado da Bahia até o Paraná, estendendo-se para oeste do Estado do Mato Grosso (Kinoshita 1979). Foi encontrada por Romão \& Souza (2003) no Parque Nacional do Caparaó em campos de altitude, capões da mata e matas ciliares, onde alcança 3-6 m alt. No PNI foi encontrada em áreas de mata de ciliar, nos rios Campo Belo e Rio d'Ouro. Fértil entre os meses setembro e outubro.

Material selecionado: BRASIL. Rio DE JANEIRo: Itatiaia, Parque Nacional do Itatiaia, Forested margins of Rio Campo Belo, 10-X-1977 P.J.M. Maas \& G. Martinelli 3162 (RB); Rio d'Ouro, IX-1934, A.C. Brade 14027 (RB); Serra do Itatiaia X-1903, P. Dusén 2124 (R).

1.4. Agarista uleana (Sleumer) Judd, J. Arnold Arbor. 65: 332. 1984.

Figura $2 \mathrm{~m}-\mathrm{r}$

Arbusto ou subarbusto, ca. $2 \mathrm{~m}$ alt., ramos glabrescentes, râmulos com tricomas ocasionalmente dispersos com glândulas esparsas; estípulas 2, ca. $1 \mathrm{~mm}$ compr.; pecíolo $0,8-1 \mathrm{~cm}$ compr., pubérulo, ocasionalmente com tricomas glandulares; lâmina discolor, elíptica a lanceolada, 2,5-6,7 × 0,9-1,9 cm, ápice acuminado a levemente agudo, base curtamente atenuada a arredondada, face adaxial pubérula, principalmente na nervura central, raramente em todo o limbo, ocasionalmente com tricomas glandulares, face abaxial pubérula principalmente na nervura central sendo esta fortemente proeminente, glabra no limbo, margem levemente revoluta. Inflorescência axilar pubescente, tricomas simples e glandulares. Flores com pedicelo de ca. $6 \mathrm{~mm}$ compr., tricomas glandulares e simples; brácteas e bractéolas lanceoladas a elípticas, inseridas na base do pedicelo, $1 \times 0,5 \mathrm{~mm}$, internamente pubescentes, tricomas glandulares e tricomas simples, externamente glabras, margem ciliada, às vezes com tricomas glandulares; cálice campanulado, ca. 1,5 mm compr., lobos do ápice triangulares, internamente pilosos, principalmente próximo à margem e ao ápice, externamente pubescentes com tricomas simples, às vezes com tricomas glandulares; corola alva, lobos internamente glabros, externamente pilosos, dorso glabro interna e externamente; estames ca. $6 \mathrm{~mm}$ compr., filetes ca. $5 \mathrm{~mm}$ compr., tomentosos, às vezes com tricomas glandulares, anteras ca. $1 \mathrm{~mm}$ compr.; ovário ca. $2 \mathrm{~mm}$ compr., piloso, principalmente no ápice, estilete $5 \mathrm{~mm}$ compr., às vezes com alguns tricomas simples, principalmente na base. Cápsula depresso-globosa, 5-6 mm diâm.

Agarista uleana (Sleumer) Judd é endêmica do Estado do Rio de Janeiro, entre o litoral e a região do Itatiaia, no limite com o Estado de São Paulo (Kinoshita 1979, Kinoshita \& Romão 2012). Ocorre também em fragmentos florestais bem conhecidos nas cidades do Rio de Janeiro (Floresta da Tijuca), Macaé e Teresópolis (Serra dos Órgãos). No PNI foi encontrada apenas em altitudes acima de $2.000 \mathrm{~m}$. Coletada fértil em junho.

Material examinado: BRASIL. Rio DE JANEIRO: Itatiaia, Parque Nacional Itatiaia, Serra do Itatiaia, 11-VI-1902, P. Dusén 529 (R).

\section{Gaultheria L.}

Arbusto ou subarbusto, ramos cilíndricos. Folhas com uma glândula enegrecida no ápice. Flores solitárias ou dispostas em inflorescência racemosa, axilar; pedicelos com uma bráctea basal e duas bractéolas inseridas acima desta; cálice geralmente campanulado 4-5-lobado; corola alva a avermelhada, 
urceolada ou campanulada, 4-5-lobada; androceu com 10 estames, inseridos na base do ovário, geralmente homodínamos, decíduos; filetes subulados, não geniculados, anteras bilobadas, lobos com ápice bidentado ou biaristado; ovário súpero não aderido a parede do receptáculo, 4-5-locular, pluriovular; estilete cilíndrico, reto; estigma truncado. Fruto cápsula.

Gaultheria apresenta 130 espécies distribuídas pelo Himalaia, leste dos Estados Unidos e Sudeste do Brasil (Stevens et al. 2004).

2.1. Gaultheria bradeana Sleumer, Bot. Jahrb. 75(4): 446. 1952.

Figura 3 a-e

Arbusto ou subarbusto, ca. 2,5 m alt., ramos pubescentes com tricomas simples, externamente curtos, raramente glandulares. Folhas com pecíolos curtos, ca. $1 \mathrm{~mm}$ compr., tricomas simples, muito raramente glandulares; lâminas subcoriáceas, discolores, ovadas a elípticas, 1,2-1,8 $\times 0,4-1 \mathrm{~cm}$, ápice acuminado a mucronado, base curtamente atenuada a obtusa, ambas as faces glabras, margem serrada, principalmente próximo ao ápice, levemente revoluta mais próximo da base, com tricomas glandulares. Flores solitárias; pedicelo ca. $2 \mathrm{~mm}$ compr., pubescente, tricomas simples; bráctea ovada a lanceolada, 1,5-2 × $1 \mathrm{~mm}$, internamente pubérula, externamente glabra, margem ciliada, tricomas glandulares curtos; bractéolas ovadas, ca. $2 \times 1 \mathrm{~mm}$, ambas as faces glabras, margem ciliada, tricomas glandulares; cálice campanulado, ca. $3 \times 3 \mathrm{~mm}$, ápice acuminado, face interna pubérula, externamente, margem glabra; corola nitidamente campanulada, alva ou rósea, glabra, lobos ca. $1 \mathrm{~mm}$ compr.; tubo da corola ca. $2 \mathrm{~mm}$ compr.; estames, ca. 1,5 mm compr., filetes ca. $1 \mathrm{~mm}$ compr., retos, tricomas glandulares diminutos, anteras ca. 0,5 $\mathrm{mm}$ compr., apículos rudimentares, bífidos; ovário ca. $1 \mathrm{~mm}$ compr., glabro, estilete ca. $3 \mathrm{~mm}$ compr., glabro, estigma plano. Cápsula subglobosa, com 5 valvas radiais, septos membranáceos.

Distribui-se nos Estados do Rio de Janeiro, Minas Gerais, São Paulo e Santa Catarina (Kinoshita 1979). Segundo Marques (1975), em Santa Catarina a espécie é característica e exclusiva da "Zona de Matinha Nebular" em picos de morros. Foi coletada no PNI exclusivamente nas áreas de campos de altitude, onde há grande exposição ao sol aliada a umidade relativa alta durante a maior parte do ano. Luthein (1995) refere-se a essa espécie como rara e ameaçada de extinção. Encontrada fértil entre os meses de abril e dezembro.

Material selecionado: BRASIL. Rio DE JANEIRO: Itatiaia, Parque Nacional do Itatiaia, Planalto, 15-IV-1973, M. Emmerich 3724 (R); XII-1895, E. Ule 187 (R); Serra da Pedra assentada, Retiro de ramos, 22-VI-1902, P. Dusén 581 (R).

2.2. Gaultheria eriophylla (Pers.) Sleumer ex Burtt var. eriophylla, Bot. Mag., n.s. 170: t. 254. 1995. Figura $3 \mathrm{k}-\mathrm{p}$

Arbusto ou subarbusto, 0,5-2,5 m alt.; ramos vilosos com tricomas simples, algumas vezes glandulares, ferrugíneos. Folhas com pecíolos 4-7 mm compr., tomentosos, ferrugíneos, tricomas simples, ocasionalmente glandulares; lâminas coriáceas, discolores, ovadas a elípticas, 4,5-7,6 × 2,5-3,4 cm, ápice longamente acuminado, fortemente mucronado, com uma glândula enegrecida, base arredondada a obtusa, face abaxial flocosa, com tricomas simples, ferrugíneos, às vezes glandulares, face adaxial tomentosa, pubescente sobre as nervuras secundárias, com tricomas simples, margem revoluta, tomentosa, tricomas simples, ferrugíneos, às vezes glandulares. Inflorescência com tricomas simples, ferrugíneo-vilosos, raramente glandulares. Flores com pedicelo 0,7-1 cm compr., tricomas simples, ferrugíneo-vilosos, às vezes glandulares; bráctea ovada, ca. $7 \times 3 \mathrm{~mm}$, internamente glabra, externamente vilosa, com indumento ferrugíneo composto por tricomas simples, ocasionalmente glandulares, margem ciliada, tricomas simples, longos, às vezes glandulares; bractéolas linear-lanceoladas, inseridas acima do pedicelo, ca. $3,7 \times 1 \mathrm{~mm}$, face interna glabra, externamente vilosa, tricomas simples, ferrugíneos, ocasionalmente glandulares, margem vilosa, tricomas simples, ferrugíneos, às vezes glandulares; cálice campanulado ca. $3 \times 1,5 \mathrm{~mm}$, ápice acuminado, face interna pubérula, contornando a margem em direção ao ápice, externamente vilosa com tricomas simples, ferrugíneos, às vezes glandulares, margem vilosa com tricomas simples, ferrugíneos, às vezes glandulares; corola rósea, internamente pubérula, externamente vilosa, indumento ferrugíneo, composto por tricomas simples e glandulares, lobos ca. $1 \mathrm{~mm}$ compr., tubo da corola ca. $5 \mathrm{~mm}$ compr., internamente pubérulo, externamente com tricomas simples, ferrugíneos, às vezes glandulares; estames ca. $4 \mathrm{~mm}$ compr., filetes ca. $3 \mathrm{~mm}$ compr., retos, vilosos, tricomas simples, 


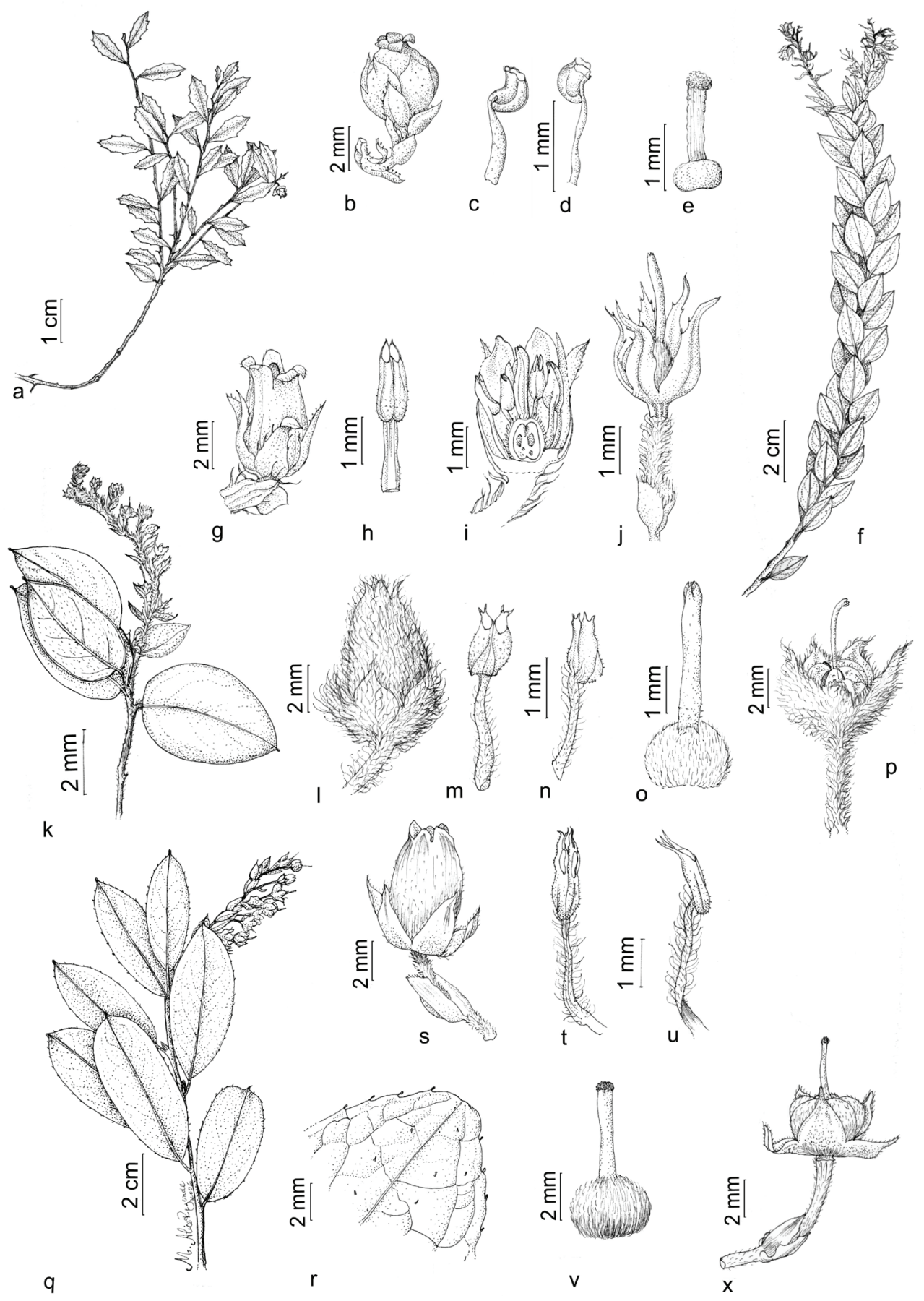

Figura 3. a-e. Gaultheria bradeana Sleumer. a. Ramo florífero. b. Flor em botão. c. Estame em vista dorsal. d. Estame em vista lateral. e. Gineceu (Markgraf 21266). f-i. Gaultheria itatiaiae Wawra. f. Ramo florífero. g. Flor. h. Estame em vista ventral. i. Corte longitudinal da flor evidenciando os óvulos (C. Porto 182). j. Fruto jovem (A.C. Brade 15574). k-p. Gaultheria eriophylla (Pers.) Sleumer ex Burtt var. eriophylla. k. Ramo florífero. 1. Flor. m. Estame em vista ventral. n. Estame em vista dorsal. o. Gineceu. p. Fruto (A.B. Pereira 31). q-x. Gaultheria serrata (Vell.) Sleumer ex Kin.-Gouv. var. serrata. q. Ramo florífero. r. Ápice foliar. s. Flor em botão. t. Estame em vista ventral. u. Estame em vista dorsal. v. Gineceu (D.R. Hunt 6417). x. Fruto (L.R. Landrum 2124).

Figure 3. a-e. Gaultheria bradeana Sleumer. a. Flowering branch. b. Flower bud. c. Stamen, dorsal view. d. Stamen, lateral view. e. Gynoecium (Markgraf 21260). f-i. Gaultheria itatiaiae Wawra. f. Flowering branch. g. Flower bud. h. Stamen, ventral view. i. Flower in longitudinal section, showing the ovules (C. Porto 182). j. Young fruit (A.C. Brade 15574). k-p. Gaultheria eriophylla (Pers.) Sleumer ex Burtt var. eriophylla. k. Flowering branch. 1. Flower. m. Stamen, ventral view. n. Stamen, dorsal view. o. Gynoecium. p. Fruit (A.B. Pereira 31). q-x. Gaultheria serrata (Vell.) Sleumer ex Kin.-Gouv. var. serrate. q. Flowering branch. r. Leaf apex. s. Flower bud. t. Stamen, ventral view. u. Stamen, dorsal view. v. Gynoecium (D.R. Hunt 6417). x. Fruit (L.R. Landrum 2124). 
ferrugíneos, tricomas glandulares diminutos; anteras ca. 1,5 mm compr., bífidas, com apículos notáveis; ovário ca. 1,5 mm compr., piloso, estilete ca. $3 \mathrm{~mm}$ compr., cilíndrico, estigma plano. Cápsula inclusa no cálice alargado, carnoso, preto, ca. $5 \mathrm{~mm}$ diâm.

A espécie possui distribuição disjunta entre Brasil, Sul do Peru e Norte da Bolívia, em elevações de (950-)1.600-2.250(-3.000) $\mathrm{m}$ (Luthein 1995). No Sudeste do Brasil, está distribuída nos Estados do Espírito Santo, Minas Gerais, Rio de Janeiro e São Paulo (Kinoshita 1979). No Parque Nacional do Caparaó foi encontrada em campos de altitude e capões de mata (Romão \& Souza 2003). Espécie relativamente comum no Parque, podendo ser observada na estrada para as Agulhas Negras e Abrigo Rebouças. Coletada fértil entre os meses de junho e novembro.

Material selecionado: BRASIL. Rio DE JANEIRo: Itatiaia, Parque Nacional do Itatiaia, Along to road to Agulhas Negras, 18-X-1977, L.R. Landrum 2130 (RB); Caminho do Abrigo Rebouças-Prateleiras, 13-VI-1960, H.F. Martins 153 (GUA); Caminho das Prateleiras, H. Bittencourt \& J.C. Bittencourt 122 (GUA); Estrada para a parte alta do Parque, 20-VIII-2004, V.P. Mezabarba 41 (RB); Planalto, 13-IX-1994, R. Guedes et al. 2403 (RB); Prateleiras, 9-XI-1969, J.P.P. Carauta 932 (GUA).

2.3. Gaultheria itatiaiae Wawra, Oest. Bot. Z. 31: 280. 1881 .

Figura $3 \mathrm{f}-\mathrm{i}$

Arbusto ou subarbusto, 0,3-1 m alt., ramos estriados, estrigosos, tricomas extremamente longos. Folhas curtamente pecioladas; pecíolo ca. 1-2 mm compr., estrigoso, tricomas longos, lâminas coriáceas, discolores, ovadas a elípticas, 2,4-3,3 × 0,6-1,1 cm, ápice acuminado, base obtusa a arredondada, face adaxial glabra, face abaxial estrigosa, margem ligeiramente crenada, ciliada ou com cicatrizes avermelhadas dos tricomas. Inflorescências vilosas, tricomas simples. Flores com pedicelo 3-4 mm compr., viloso; bráctea lanceolada, ca. $7 \times 2 \mathrm{~mm}$, internamente pubérula e externamente estrigosa, margem ciliada, tricomas glandulares curtos; bractéolas ovadas a obovadas, inseridas acima do pedicelo, ca. $3 \times 1 \mathrm{~mm}$ compr., ambas as faces com tricomas simples dispersos, margem ciliada, tricomas simples, curtos; cálice campanulado, ca. $5 \times 2 \mathrm{~mm}$, ápice lanceolado, face interna com tricomas curtos, principalmente no ápice e próximo da margem, face externa estrigosa com tricomas longos, margem levemente estrigosa com tricomas glandulares, tricomas simples curtos próximo ao ápice; corola alva, lobos 1-2 mm compr., internamente pubérulos, externamente glabrescentes, tubo da corola ca. $3 \mathrm{~mm}$ compr., internamente tricomas simples longos, ligeiramente adpressos, externamente glabrescente; estames ca. $4 \mathrm{~mm}$ compr., filetes ca. $2 \mathrm{~mm}$ compr., retos, tricomas glandulares diminutos, anteras ca. $2 \times 1 \mathrm{~mm}$, levemente estreitadas apicalmente, parecendo tubos pequenos, bífidos; ovário ca. $2 \mathrm{~mm}$ compr., viloso, estilete ca. $3 \mathrm{~mm}$ compr., tricomas curtos, principalmente na base, estigma plano. Cápsula depresso-globosa, com 5 valvas radiais, septos consistentes, persistentes.

Estende-se dos Estados do Rio de Janeiro e Minas Gerais (Itatiaia) até o Rio Grande do Sul, ao longo da Serra do Mar, Mantiqueira e Serra Geral (Kinoshita 1979, Silva \& Cervi 2006). Esta planta tem como localidade típica o Parque Nacional de Itatiaia, na região do Planalto. Luthein (1995) considerou esta espécie endêmica da zona nebular de Santa Catarina, talvez pela falta de acesso a outros materiais. Coletada fértil entre os meses de dezembro e junho.

Material selecionado: BRASIL. Rio DE JANEIRO: Itatiaia, Parque Nacional do Itatiaia, VI-1913, F.T. Toledo Jr. \& A.C. Brade 728 (RB); XII-1934, R.K.F. Pilger \& A.C. Brade 46 (RB); Caminho do Abrigo Rebouças-Prateleiras, 13-III-1960, F. Atala 296 (GUA); Planalto, III-1937, A.C. Brade 15574 (RB); Planalto, 8-II-1945, A.C. Brade 17547 (RB); Final da estrada para o Pico das Agulhas Negras, 26-IV-1995, J.M.A. Braga et al. 2334 (RB); 1915, C. Porto 182 (RB).

2.4. Gaultheria myrtilloides Cham. \& Schlcht., Linnaea 1: 523. 1826.

Arbusto ou subarbusto, 0,5-0,8 m alt., ramos pubérulo-hirsutos, com tricomas simples, esbranquiçados e ferrugíneos, glandulares. Folhas com pecíolo de 1-3 mm compr., glabro a hirsuto, tricomas simples; lâminas coriáceas, discolores, ovadas a elípticas, $1-2,5 \times 0,4-1,2 \mathrm{~cm}$, ápice curtoacuminado, não mucronado, base arredondada a obtusa, face adaxial glabra a hirsuta, face abaxial estrigosa a hirsuta, margem ligeiramente serrada, revoluta. Flores solitárias; pedicelo 2-3,5 $\mathrm{mm}$ compr., pubescente, tricomas simples; bráctea ovada, 1,5-2 $\times 1 \mathrm{~mm}$, internamente e externamente glabra, margem ciliada; bractéolas ovadas, ca. $2 \times 1 \mathrm{~mm}$, ambas as faces glabras, margem ciliada; cálice 
campanulado 2-3,5 × 2-3 mm, ápice acuminado, faces interna e externa pubérulas; corola nitidamente campanulada, alva, glabra, lobos ca. $1 \mathrm{~mm}$ compr.; tubo da corola 3-3,5 mm compr.; estames, 1,5-2,5 mm compr., filetes 1-1,5 mm compr., retos, glabros, anteras 1-1,5 mm compr., apículos diminutos, bífidos; ovário ca. 1,5 mm compr., glabro, estilete ca. $2 \mathrm{~mm}$ compr., glabro, estigma clavado. Cápsula globosa, com 5 valvas radiais, septos cartáceos.

Espécie próxima a G. bradeana e G. ulei pelas flores solitárias com corola campanulada e apículos das anteras inconspícuos. Difere de G. bradeana, a única das duas espécies que ocorre no Parque, por apresentar folhas coriáceas com ápice não mucronado (versus subcoriáceas com ápice mucronado em G. bradeana). Coletada fértil em novembro. Iconografia: Meisner in Martius (1863): Fl. bras. 7: 149, t. 56, fig. 1.

Material examinado: BRASIL. RIO DE JANEIRO: Itatiaia, Pico de Itatiaia, XI-1843, H.A. Weddell 1555 (G, P).

2.5. Gaultheria serrata (Vell.) Sleumer ex Kin.-Gouv. var. serrata, Brittonia 41(1): 161989.

Figura $3 \mathrm{q}-\mathrm{x}$

Arbusto ou subarbusto ca. $2 \mathrm{~m}$ alt., ramos estriados, tricomas glandulares. Folhas com pecíolo 4-7 mm compr., tricomas glandulares; lâminas coriáceas, discolores ovadas a elípticas, raramente oblongas, 4-6,1 × 1,5-3,5 cm, ápice agudo a mucronado, base arredondada a obtusa, ambas as faces com tricomas glandulares, menos numerosos na face adaxial, levemente estrigosa ou com cicatrizes avermelhadas dos tricomas, margem moderadamente crenada a serrada, tricomas glandulares ou com cicatrizes avermelhadas dos tricomas. Inflorescência pubescente a tomentosa, com tricomas glandulares e simples. Flores com pedicelo 5-7 mm compr., tomentoso, tricomas glandulares, simples, bráctea ovada, ca. $9 \times 4 \mathrm{~mm}$ compr., internamente pubérula, externamente glabra, margem ciliada, tricomas simples; bractéolas ovadas, elípticas ou lanceoladas, ca. $5 \times 1 \mathrm{~mm}$, ambas as faces pubescentes, margem ciliada com tricomas simples e tricomas glandulares; cálice campanulado, ca. $5 \times 2 \mathrm{~mm}$, ápice acuminado, face interna pubérula, externamente glabrescente, margem ciliada com tricomas simples e glandulares; corola rósea, internamente tomentosa, externamente pubescente, lobos ca. $1 \mathrm{~mm}$ compr., tubo da corola ca. $7 \mathrm{~mm}$ compr.; estames ca. $4 \mathrm{~mm}$ compr., filetes ca. $2 \mathrm{~mm}$ compr., retos, tricomas glandulares, diminutos e tricomas simples, longos, raramente glandulares, anteras 1-1,6 mm compr., bífidas com apículos notáveis; ovário ca. 1,5 mm compr., tomentoso, tricomas simples, às vezes tricomas glandulares, estilete ca. $4 \mathrm{~mm}$ compr., piloso principalmente na base, estigma plano. Cápsula globosa, 5-costada, pubescente.

Ocorre desde o limite dos Estados do Espírito Santo e Minas Gerais (Serra do Caparaó) até o Paraná. A espécie é a que apresenta a distribuição mais ampla no PNI, de ocorrência frequente nas diversas áreas do planalto. Encontrada fértil entre os meses de fevereiro e dezembro.

Material selecionado: BRASIL. Rio DE JANEIRO: Itatiaia, Parque Nacional do Itatiaia, V-1906, $H$. Luederwaldt 490 (SP); XII-1915, C. Porto 167 (RB); II-1947, A. Lutz s.n. (R); Agulhas Negras, 30-VI-1969, D. Sucre \& T. Plowmann 5146 (RB); Caminho da Prateleiras, J.C. Bittencourt \& H. Bittencourt 73 (GUA); Estrada para a parte alta do parque, 20-VIII-2004, V.P. Mezabarba 42 (RB); Planalto do Itatiaia, Várzea das flores, 29-XI-1921, B. Lobo 21 (R); Serra do Itatiaia, 4-10-VI-1913, A.C. Brade \& F.T. Toledo 6408 (SP).

\section{Gaylussacia Kunth}

Arbustos, geralmente ramificados, ramos cilíndricos. Folhas coriáceas, margem inteira, revoluta a serreada. Flores dispostas em inflorescência racemosa, axilar, terminal ou subterminal; pedicelos com uma bráctea basal e duas bractéolas inseridas acima desta; cálice campanulado, 5-lobado; corola alva, rósea ou vermelha, campanulada, urceolada ou tubulosa, 5-lobada; androceu com 10 estames, homodínamos, persistentes, filetes subulados, não geniculados, anteras tubulosas, bífidas, mais ou menos até a inserção do filete; ovário ínfero, aderido a parede do receptáculo, pseudo-10-locular, 1 óvulo para cada lóculo, estilete reto, estigma truncado. Fruto nuculânio.

Gaylussacia possui cerca de 48 espécies, com distribuição desde os Estados Unidos até o norte da Argentina e Sudeste do Brasil (Stevens et al. 2004). No Brasil, é registrada a ocorrência de aproximadamente 37 espécies do gênero (Silva \& Cervi 2006).

Gaylussacia octosperma Gardner, $G$. pseudogaultheria Cham. \& Schltdl., G. vitis-idaea Mart. e G. riedelii Meisn., citadas por Brade (1956) como tendo ocorrência para o PNI, não foram encontradas na área estudada. 
3.1. Gaylussacia amoena Cham., Linnaea 8: 501. 1833.

Figura 4a-e

Arbusto, ca. $1 \mathrm{~m}$ alt., ramos extremamente ramificados, râmulos com tricomas curtos pubérulos parecendo cerdas. Folhas com pecíolo $2 \mathrm{~cm}$ compr., tricomas simples, curtos, tricomas glandulares em pouca quantidade, lâminas concolores, obovadas a elípticas, 1,2-2 × 0,4-0,6 cm, ápice mucronado, base curtamente atenuada, face adaxial pubérula, tricomas simples, curtos, distribuídos em toda a extensão da lâmina ou esparsos, principalmente na base e nas nervuras, margem ciliada, tricomas simples e glandulares. Inflorescência terminal, pubescente, às vezes com tricomas glandulares. Flores pediceladas, pedicelo 4-5 $\mathrm{mm}$ compr., tricomas simples e glandulares, na base do pedicelo, bráctea levemente romboide, $4,5 \times 2,8 \mathrm{~mm}$, internamente glabra, externamente com tricomas simples que ficam mais concentrados na base, e tricomas glandulares, margem ciliada com tricomas simples e glandulares em toda a extensão, bractéolas 2 , acima da bráctea, ambas ca. $3 \times 1 \mathrm{~mm}$ compr., lanceoladas, glabras interna e externamente, margem ciliada, tricomas simples; cálice ca. $2 \mathrm{~mm}$ compr., campanulado, interna e externamente glabro, tricomas glandulares; corola ca. $8 \mathrm{~mm}$ compr., largamente campanulada, alva, lobos $3 \mathrm{~mm}$ compr., internamente e externamente glabros, dorso ca. $5 \mathrm{~mm}$ compr., interna e externamente glabro; estame ca. 5,5 mm compr., filetes ca. $2 \mathrm{~mm}$ compr., pubescente, mais curto que as anteras; ovário ca. $1,5 \mathrm{~mm}$ compr., glabro, estilete $8 \mathrm{~mm}$ compr., glabro, estigma levemente globoso. Nuculânio depresso-globoso, ca. $3 \mathrm{~mm}$ diâm.

Ocorre na região sudeste do Estado de Minas Gerais, Sul do Rio de Janeiro e Leste de São Paulo, Paraná até Rio Grande do Sul. Silva \& Cervi (2006) indicaram que $G$. amoena provavelmente é uma espécie rara e que, no Estado do Paraná é conhecida somente na Floresta Ombrófila Densa Alto Montana. No PNI ocorre na estrada para as Agulhas Negras e no Planalto. Encontrada fértil de maio a dezembro.

Material selecionado: BRASIL. Rio DE JANEIRo: Itatiaia, Parque Nacional do Itatiaia, Base das Agulhas, XI-1938, F. Markgraf \& Brade 3713 (RB); Estrada para o Abrigo Rebouças, margem direita, 4-VII-1983, L. Sylvestre $58(\mathrm{R})$; Estrada para do planalto, 5-XII-1964, H.E. Strang 622 (GUA); Estrada para as Prateleiras, 4-VII-1983, J. Cardoso \& J.W. Floyd 229 (R); Planalto, Agulhas Negras, via tradicional para o cume, 27-IX-1995, J.M.A. Braga et al. 2864 (RB); Planalto próximo ao Abrigo Rebouças, 6-XI-1976, G. Martinelli \& J. Fontella 1077 (RB); Pico da Agulhas Negras, 1-V-1977, D.M. Vital 4864 (SPF); Serra do Itatiaia, 22-V-1930, A.C. Brade 10126 (R).

3.2. Gaylussacia brasiliensis (Spreng.) Meisn. var. brasiliensis, Fl. Bras. 7: 129. 1863.

Figura $4 \mathrm{q}-\mathrm{u}$

Arbusto, 0,5-2,5 m alt., ramos glabrescentes. Folhas com pecíolo 0,5-2 mm compr., moderadamente espesso, glabrescente ou glabro; lâminas concolores, de formas variadas às vezes no mesmo espécime, de oblongo-elípticas, raro elípticas, a obovado-elípticas ou obovado-oblongas, 2,7-4,8 × 3,1-2,1 cm, ápice atenuado-subagudo ou obtuso podendo apresentar uma glândula no término da nervura central, base obtusa a arredondada, face abaxial glabra ou glabrescente, brilhante, face adaxial com tricomas simples, proeminentes; margem recurvada, inteira. Inflorescências axilares, variando de glabras a densamente pubescentes. Flores com pedicelo 4-8 mm compr., piloso, tricomas glandulares; brácteas oblongas a obovadas, ou lanceoladas, tricomas simples, às vezes tricomas glandulares interna e externamente, margem ciliada, $7 \times 3 \mathrm{~mm}$ compr.; bractéolas setáceas, inseridas na região mediana do pedicelo; cálice campanulado, ca. $1,5 \mathrm{~mm}$ compr., pubescente, recoberto por glândulas muricadas, ou glabro; corola 7-9 mm compr., rósea a vermelha, às vezes externamente pilosa nos ângulos e internamente glabra; estame com filetes 2,5-3 mm compr., piloso na margem ou na parte superior; ovário glabro, estilete 7-9 mm compr., delgado, glabro. Nuculânio subgloboso, 5-6 mm diâm.

Esta espécie está amplamente distribuída pelo Brasil, desde o Estado da Paraíba até o Rio Grande do Sul ao longo da costa, para o oeste até o Mato Grosso do Sul e Goiás. Embora seja uma das espécies mais comuns da família, ocorrendo desde a vegetação de restinga e topos de morro. No Parque de Itatiaia é conhecida apenas por uma única coleta. O polimorfismo foliar de G. brasiliensis, também ressaltado por Silva \& Cervi (2006), pode ser relacionado aos diferentes ambientes ocupados pela espécie. Coletada fértil em abril, sendo que os frutos desta espécie são indicados como comestíveis.

Material examinado: BRASIL. RIO DE JANEIRO: Itatiaia, Parque Nacional, Pico do Itatiaia, IV-1921, B. Lobo s.n.(R92745). 


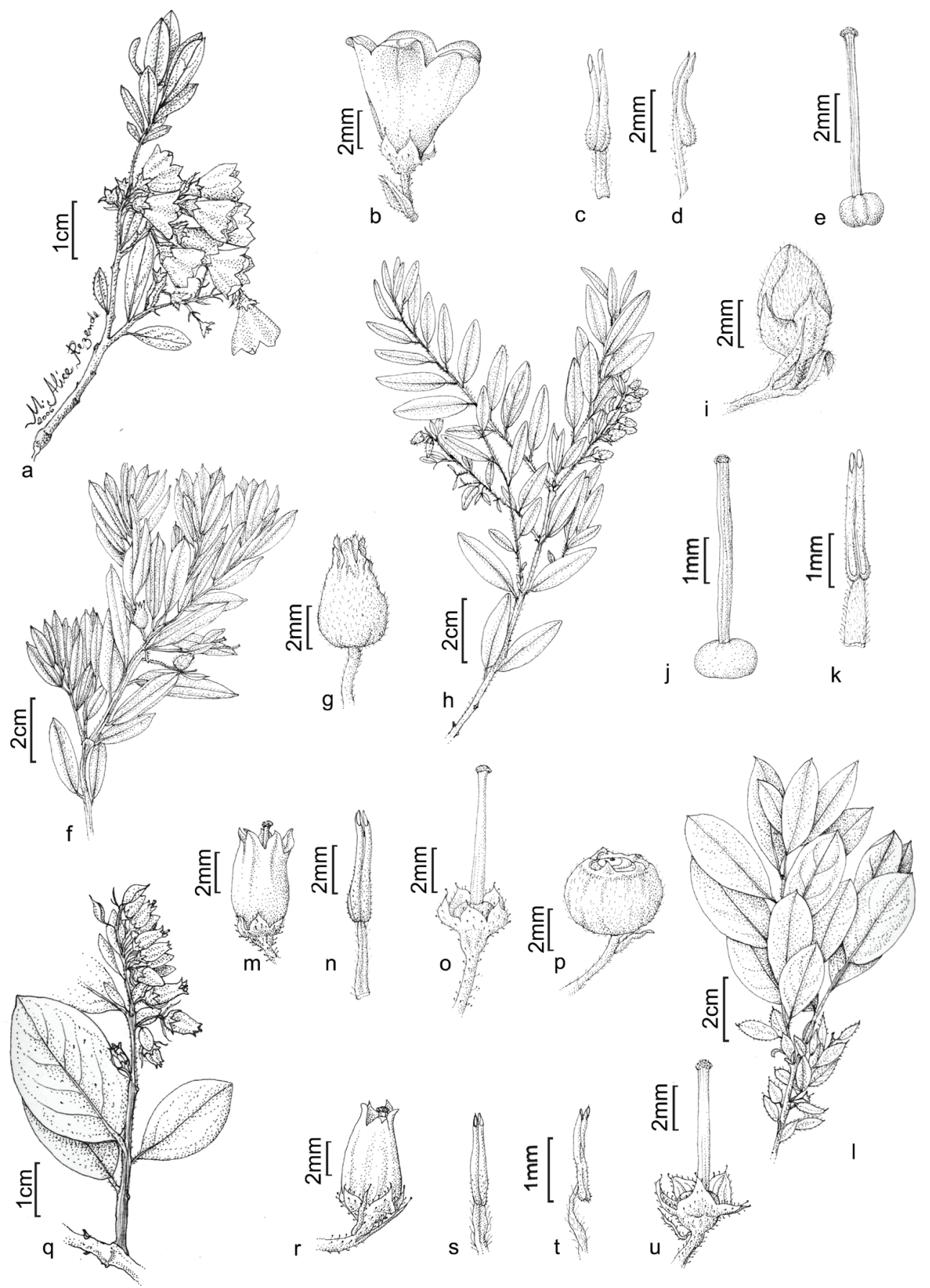

Figura 4. a-e. Gaylussacia amoena Cham. a. Ramo florífero. b. Flor. c. Estame em vista ventral. d. Estame em vista lateral. e. Gineceu (J.M.A. Braga 2866). f-g. Gaylussacia decipiens Cham. f. Ramo florífero. g. Flor em botão (P. Schwacke 12131). h-k. Gaylussacia chamissonis Meissner. h. Ramo florífero. i. Flor em botão. j. Gineceu k. Estame em vista ventral (F. Markgraf 3648). 1-p. Gaylussacia fasciculata Gardner. 1. Ramo florífero. m. Flor. n. Estame em vista ventral. o. Gineceu com cálice e pedicelo (G. Martinelli 13252). p. Fruto (R. Guedes 2327). q-u. Gaylussacia brasiliensis (Spreng.) Meissner var. brasiliensis. q. Ramo florífero. r. Flor em botão. s. Estame em vista ventral. t. Estame em vista lateral. u. Gineceu (B. Lobo s.n. R92745).

Figure 4. a-e. Gaylussacia amoena Cham. a. Flowering branch. b. Flower. c. Stamen, ventral view. d. Stamen, lateral view. e. Gynoecium (J.M.A. Braga 2860). f-g. Gaylussacia decipiens Cham. f. Flowering branch. g. Flower bud (P. Schwacke 12131). h-k Gaylussacia chamissonis Meissner. h. Flowering branch. i. Flower bud. j. Gynoecium. k. Stamen, ventral view (F. Markgraf 3648). 1-p. Gaylussacia fasciculata Gardner. 1. Flowering branch. m. Flower. n. Stamen, ventral view. o. Gynoecium with calyx and pedicel (G. Martinelli 13252). p. Fruit (R. Guedes 2327). q-u. Gaylussacia brasiliensis (Spreng.) Meissner. q. Flowering branch. r. Flower bud. s. Stamen, ventral view. t. Stamen, lateral view. u. Gynoecium (B. Lobo s.n. R92745). 
3.3. Gaylussacia chamissonis Meisn., Fl. Bras. 7: 144. 1863.

Figura $4 \mathrm{~h}-\mathrm{k}$

Arbusto, 1-2 m alt., ramos subcerdosos, com tricomas longos, glândulas estipitadas, dispersas. Folhas com pecíolo ca. $2 \mathrm{~cm}$ compr., tricomas longos, subcerdosos, glândulas estipitadas, dispersas, lâmina concolor, oblonga a elíptica, 1,4-2,1 × 0,4-0,7 cm, ápice arredondado com uma glândula enegrecida, base atenuada, ambas as faces subcerdosas, com tricomas longos, glândulas estipitadas, dispersas; margens levemente revolutas, com os mesmos tricomas das lâminas. Inflorescência terminal, subcerdosa, com tricomas longos, glândulas estipitadas, dispersas. Flores com pedicelo 2-3 mm compr., subcerdoso, tricomas longos, glândulas estipitadas, dispersas; brácteas lanceoladas, ca. 4,5 ×2,8 mm, internamente glabras, externamente subcerdosa, com tricomas longos, glândulas estipitadas, dispersas, margem ciliada; bractéolas lanceoladas, inseridas acima do pedicelo, $3 \times 1 \mathrm{~mm}$, interna e externamente glabras, margem ciliada, tricomas simples; cálice campanulado, ca. $2 \mathrm{~mm}$ compr., subcerdoso, interna e externamente com tricomas longos, glândulas estipitadas, dispersas; corola tubuloso-campanulada, ca. $6 \mathrm{~mm}$ compr., alva, lobos ca. $3 \mathrm{~mm}$ compr., internamente glabra, subcerdosos, externamente com tricomas longos, glândulas estipitadas, dispersas, em menor quantidade do que nas outras partes da planta, dorso $3 \mathrm{~mm}$ compr., subcerdoso, internamente glabro, externamente com tricomas longos, glândulas estipitadas, dispersas, em menor quantidade do que nas outras partes da planta; estames ca. $4 \mathrm{~mm}$ compr., filetes ca. 1,5 mm compr., subcerdosos, tricomas longos glândulas estipitadas, dispersas, anteras ca. $2,5 \mathrm{~mm}$ compr.; ovário ca. 1,5 mm compr., glabro, estilete ca. $8 \mathrm{~mm}$ compr., glabro, delgado, estigma levemente globoso. Nuculânio subgloboso, esparsamente piloso a glanduloso, 4-5 mm diâm.

A espécie ocorre nos Estados de Minas Gerais e Rio de Janeiro, nas imediações do Estado de São Paulo. É conhecida da região no Planalto de Itatiaia por poucas coletas. Encontrada fértil entre os meses de novembro e maio.

Material selecionado: BRASIL. Rio DE JANEIRo: Itatiaia, Parque Nacional do Itatiaia, V-1945, A.C. Brade 17404 (RB); XI-1952, A.C. Brade 21268 (RB); Abrigo Rebouças, 30-XII-1966, H. Strang \& A. Castellanos 803 (HB); Campos do Itatiaia,
H. Leuderwaldt s.n. (SP15957); Planalto, 6-III-1962, E. Pereira 7051 (HB); Prateleiras, Planalto, 8-V-1975, A.M. Caminil 4445 (RB); Serra do Itatiaia, 14-V-1902, P. Dusén 51 (R).

3.4. Gaylussacia decipiens Cham., Linnaea 8: 500. 1833.

Figura 4f-g

Arbusto, 1-2 m alt., ramos com organização corimbiforme, tomentosos a hirsutos. Folhas com pecíolo 2-4 $\mathrm{mm}$ compr., tomentoso, tricomas simples; lâminas levemente discolores, oblongas a elípticas, 2-3,5 × 0,4-1,2 cm, ápice arredondado a obtuso, base cuneada a curtamente atenuada, ambas as faces com tricomas simples e glândulas clavadas; margens extremamente revolutas, tricomas glandulares. Inflorescência axilar ou subterminal, delgada, densamente pilosa, levemente clavadoglandulosa. Flores com pedicelo 2-4 mm compr., densamente piloso, ocasionalmente com glândulas clavadas; brácteas oblongas ou espatulado-oblongas, agudas, 4-5 mm compr., glabrescentes, ápice agudo; bractéolas filiformes, 3-4 mm compr., inseridas na região mediana do pedicelo; cálice campanulado, alvo-piloso a viloso, lobos estreitamente deltoides, subagudos, esparsamente pilosos, ca. 1,5 mm compr.; corola alva, 6-7 mm compr., largamente campanulada, externamente pilosa nos ângulos, internamente glabra tanto nos lobos quanto no dorso; estame ca. $2 \mathrm{~mm}$ compr., filetes ca. 1,7 mm compr., pilosos; parte superior do ovário pilosa, estilete $2,8 \mathrm{~mm}$ compr., delgadamente colunar, piloso na base. Nuculânio subgloboso, esparsamente pubescente, ca. $4 \mathrm{~mm}$ diâm.

Ocorre principalmente no Estado de Minas Gerais, ocasionalmente nos Estados do Rio de Janeiro, São Paulo e Mato Grosso do Sul. No Parque é conhecida por uma única coleta sem localização precisa. Indicada como fértil em fevereiro.

Material examinado: BRASIL. Rio DE JANEIRO: Itatiaia, Parque Nacional do Itatiaia, Serra do Itatiaia, II-1894, E. Ule 56 (R); VII-1902, C. Moreira \& Moreira s.n. (R92972).

Material adicional: BRASIL. Minas GeRAIS: Serra de Tripuhy, 20-I-1896, P. Schwacke 12131 (RB).

3.5. Gaylussacia fasciculata Gardner, Lond. J. Bot. 4: 131.1845.

Figura 4 1-p

Arbusto ca. $1 \mathrm{~m}$ alt., ramos com tricomas simples e glandulares. Folhas com pecíolo 1-1,5 cm 
compr., tricomas simples, longos a médios, tricomas glandulares, lâmina discolor, oblonga a obovada, 2,5-4,2 × 0,9-1,9 cm, ápice atenuado a obtuso, base cuneada a arredondada, face adaxial com tricomas simples, mais frequentes na nervura central, face abaxial nítida, com tricomas glandulares; margem levemente revoluta, às vezes com tricomas glandulares. Inflorescência axilar, com tricomas simples e glandulares. Flores com pedicelo ca. 0,5 mm compr., tricomas simples e glandulares; brácteas lanceoladas, ca. $1 \times 3 \mathrm{~mm}$, internamente glabras, externamente com tricomas simples e glandulares, margem ciliada; bractéolas inseridas na região mediana do pedicelo, linear-lanceoladas, ca. $5 \times 1 \mathrm{~mm}$, interna e externamente com tricomas simples e glandulares, margem ciliada; cálice campanulado, ca. $3 \mathrm{~mm}$ compr., internamente glabro a glabrescente, externamente com tricomas simples e glandulares; corola ca. $5 \mathrm{~mm}$ compr., cilíndrica, dorso ca. $3 \mathrm{~mm}$ compr., lobos ca. $2 \mathrm{~mm}$ compr., glabra interna e externamente, alva ou rosada; estames ca. $7 \mathrm{~mm}$ compr., filetes ca. $3 \mathrm{~mm}$ compr., tricomas simples e longos, anteras ca. $5 \mathrm{~mm}$ compr.; ovário glabro na porção superior, estilete ca. $8 \mathrm{~mm}$ compr., glabro. Nuculânio subgloboso, ca. $3 \mathrm{~mm}$ diâm.

Ocorre principalmente nos Estados do Rio de Janeiro, Espírito Santo e Minas Gerais. No PNI é encontrada na base das Agulhas Negras e no Planalto de Itatiaia. Coletada fértil entre outubro e novembro.

Material selecionado: BRASIL. Rio DE JANEIRO: Itatiaia, Parque Nacional do Itatiaia, Planalto do Itatiaia, X-1913, A. Lutz 567 (R); Planalto, $2.000 \mathrm{~m}$ de altitude, XI-1938, F. Markgraf \& A.C. Brade 3650 (RB); XI-1938, F. Markgraf \& A.C. Brade 3713 (RB); Trilha para os Abrigos Macieiras e Macenas, 8-XI-1993, R. Guedes et al. 2327 (RB).

Material adicional: BRASIL. Rio DE JANEIRO: Santa Maria Madalena, Parque Estadual do Desengano, Serra do Desengano, Vertente noroeste, 20-XII-1988, G. Martinelli 13252 (RB).

\section{Agradecimentos}

À FAPERJ, pela bolsa concedida à primeira Autora. Agradecemos aos curadores dos herbários visitados, pela facilitação ao acesso do acervo e/ou pelo empréstimo de material botânico; ao ICMBio pela autorização e suporte durante trabalhos de campo no Parque Nacional do Itatiaia; à Maria Alice Resende pelas ilustrações e aos revisores anônimos pelas valiosas sugestões.

\section{Literatura citada}

Brade, A.C.A. 1956. Flora do Parque Nacional de Itatiaia. Boletim Parque Nacional Itatiaia 5: 1-92.

Holmgren, P.K., Holmgren, N.H. \& Barnett, L.C. 1990. Index Herbariorum, part 1: the herbaria of the world. 8 ed. New York Botanical Garden, New York.

Judd, W.S., Campbell, C.S., Kellogg, E.A., Stevens, P.F. \& Donoghue, M.J. 2009. Sistemática Vegetal: um enfoque filogenético. 3 ed. Artmed, Porto Alegre.

Kinoshita, L.S. 1979. Estudos taxonômicos e fitogeográficos da família Ericaceae no Brasil. Tese de Doutorado, Universidade de São Paulo, São Paulo.

Kinoshita, L.S. \& Romão, G.O. 2010. Ericaceae. In: R.C. Forzza, P.M. Leitman, A.F. Costa, A.A. Carvalho Jr., A.L., Peixoto, B.M.T. Walter, C. Bicudo, D. Zappi, D.P. Costa, E. Lleras, G. Martinelli, H.C. Lima, J. Prado, J.R. Stehmann, J.F.A. Baumgratz, J.R., Pirani, L. Sylvestre \& L.C. Maia (orgs.). Catálogo de Plantas e Fungos do Brasil. v.2. Andrea Jacobsson Estúdio, Jardim Botânico do Rio de Janeiro, Rio de Janeiro, pp. 934-937.

Kinoshita, L.S. \& Romão, G.O. 2012. Ericaceae In: M.G.L. Wanderley, G.J. Shepherd \& A.M. Giulietti (eds.). Flora Fanerogâmica de São Paulo. v.7. FAPESP, RiMa, São Paulo, pp. 297-321.

Kron, K.A. 1996. Phylogenetic relationships of Empetraceae, Epacridaceae, Ericaceae, Monotropaceae, and Pyrolaceae: evidence from nuclear ribosomal 18s sequence data. Annals of Botany 77: 293-303.

Kron, K.A., Fuller, R., Crayn, D.M., Gadek, P.A., \& Quinn, C.J. 1999. Phylogenetic relationships of epacrids and vaccinioids (Ericaceae s.l.) based on matK sequence data. Plant Systematics and Evolution 218: 55-65.

Lamego, A.R. 1935. O maciço do Itatiaya e regiões circundantes. Boletim do Serviço Geológico e Mineralógico 88. Ministério da Agricultura, Rio de Janeiro.

Luteyn, J.L. 1992. Speciation and diversity of Ericaceae in neotropical montane vegetation. In: L.B. Holm-Nielsen, I.C. Nielsen \& H. Baslev (eds.). Tropical forests: Botanical dynamics, speciation and diversity. Academic Press, New York, pp. 297-310.

Luteyn, J.L. 1995. Gautheria. In: J.L. Luteyn (ed.). Ericaceae - Part II. The superior-ovaried genera (Monotropoideae, Pyroloideae, Rhodondroideae, and Vaccionoideae). Flora Neotropica Monograph 66: 384-488.

MA-IBDF \& FBCN. 1982. Plano de manejo do Parque Nacional do Itatiaia. Ministério da Agricultura, Instituto Brasileiro de Desenvolvimento Florestal, Fundação Brasileira para a Conservação da Natureza, Brasília.

Marques, M.C.M. 1975. Ericáceas. Parte I. In: R. Reitz (ed.). Flora Ilustrada Catarinense. Herbário Barbosa Rodrigues, Itajaí. 
Meissner, C.F. 1863. Ericaceae. In: C.F.P. Martius (ed.). Flora Brasiliensis. v.7. Typographia Regia, Monachii, pp. 119-182.

Morim, M.P. 2002. Leguminosas arbustivas e arbóreas do Parque Nacional do Itatiaia: abordagem florísticotaxonômica. Tese de Doutorado, Universidade Federal do Rio de Janeiro, Rio de Janeiro.

Romão, G.O. \& Souza, V.C. 2003. Flora Fanerogâmica do Parque Nacional do Caparaó: Ericaceae. Pabstia 14: 1-12.

Romão, G.O., Wanderley, M.G.L. \& Yokoda, N. 2004. Flora de Grão-Mogol, Minas Gerais: Ericaceae. Boletim de Botânica da Universidade de São Paulo 22: 97-100.

Segadas-Vianna, F. \& Dau, L. 1965. Ecology of Itatiaia range, southeastern Brazil. I. Altitudinal zonation of the vegetation. Arquivos do Museu Nacional do Rio de Janeiro 53: 31-53.

Silva, R.R. \& Cervi,A.C. 1999. Gaylussacia novae (Ericaceae) Brasilia australi nuper inventae. Fontqueria 54: 4-6.

\section{Lista de exsicatas:}

Aguiar, L.F.: 4 (2.2); Altamiro: 32 (2.5), 33 (1.2); Alves, M.V.: 662 (2.5); Apparicio P.D.: 830 (3.3); Araujo, D.: 2048 (2.5); Atala, F.: 296 (2.3), 17547 (2.3); Bianchini, R.S.: 719 (2.2); Bittencourt, H.: 122 (2.2); Bittencourt, J.C.: 73 (2.5); Brade, A.C.: I-18 (3.1), 115 (2.5), 6407 (3.1), 6408 (2.5), 10126 (3.1), 10127 (2.3), 10128 (2.5), 14027 (1.3), 14086 (1.1), 14094 (1.2), 15574 (2.3.), 12687 (2.5), 17404 (3.3), 20365 (2.1) 21268 (2.3); Braga, J.M.A.: 547 (2.2), 1565 (3.1), 2334 (2.3), 2549 (1.2), 2864 (3.1), 2866 (3.1); Braga, P.I.S.: 2569 (2.5); Busset, S.N.: 16020 (3.3); Camerich, A.M.: 213 (2.5), 13151 (2.2); Caminil, A.M.: 20 (1.2), 4445 (3.3); Carauta, J.P.P.: 926 (1.2), 932 (2.2), 2900 (2.2); Cardoso, J.: 229 (3.1); Casari, M.B.: 11 (2.5), 363 (2.5), 364 (1.2); Castellanos, A.: 16 (2.5), 21945 (2.2), 25665 (3.1); Dusén, P.: 51 (3.3), 52 (1.2), 54 (2.5), 55 (3.1), 57 (2.2), 61 (2.3), 529 (1.4), 581 (2.1), 1005 (2.5), 2081 (3.1), 2124 (1.3); Emmerich, M.: 59 (2.5), 3724 (2.1); Emygdio, L.: 1420 (2.3); Ferreira, V.F.: 209 (3.1), 3634 (2.2), 3639 (2.5), 3644 (1.2), 3659 (2.2); Fidalgo, O.: 6 (2.5); Freitas, M.F.: 71 (2.5); Fromm, E.: 15 (2.2), 134 (2.3); Garcia, J.: 629 (1.2); Giordano, L.C.: 798 (2.5); Guedes, R.: 2327 (3.5), 2397 (1.2), 2398 (2.5), 2403 (2.2); Hermmendorff, E.: 578 (2.5), 586 (1.2), 599 (1.2); Hunt, D.R.: 6417 (2.5), 6443 (3.1); Kuhlmann, J.G.: s.n. RB 21918 (2.2), s.n. RB445442 (2.1); Landrum, L.R.: 2081 (1.3), 2124 (1.2), 2130 (2.2); Lobo, B.: 26 (2.3), 28 (2.3), 32 (2.3); Luederwaldt, H.: 490 (2.5), s.n. SP15957 (2.5); Lobo, B.: s.n. R92745 (3.2); Lutz, A.: 566 (2.5), 567 (3.5), s.n. R129120 (3.1);
Silva, R.R. \& Cervi, A.C. 2006. As Ericaceae Juss. nativas no Estado do Paraná, Brasil. Acta Biológica Paranaense 35: $1-45$

Souza, V.C. \& Lorenzi, H. 2008. Botânica Sistemática. Guia ilustrado para Identificação das famílias de Angiospermas da flora brasileira, baseado em APG II. 2 ed. Instituto Plantarum de Estudos da Flora, Nova Odessa.

Stevens, P.F. 2001. Taxonomic studies in the Ericaceae. Ph.D. Thesis, University of Edinburgh, Edinburgh.

Stevens, P.F., Luteyn, J., Oliver, E.G.H., Bell, T.L., Brown, E.A., Crowden, R.K., George, A.S., Jordan, G.J., Ladd, P., Lemson, K., McLean, C.B., Menadue, Y., Pate, J.S., Stace, H.M. \& Weiller, C.M. 2004. Ericaceae. In: K. Kubitzki (ed.). The families and genera of vascular plants. v.6. Springer Verlag, Berlin, pp. 145-161.

Maas, P.J.M.: 3162 (1.3), 3176 (2.2); Mansano, V.F.: 235 (2.5), 247 (2.2), 255 (2.5), 287 (2.5), 293 (2.2), 295 (1.2), 323 (2.2), 404 (1.2), 413 (2.5); Markgraf, F.: 3648 (3.3), 3650 (3.1), 3713 (3.1), 3714 (3.1), 3727 (1.2), 21264 (1.3), 21265 (1.3), 21266 (2.1), 21267 (3.1); Marquete, R.: $4074 b$ (3.5); Martinelli, G.: 1077 (3.1), 1079 (1.2), 3223 (1.2), 13252 (3.5); Martins, H.F.: 153 (2.2), $356(2.2)$; Massat, S.N.: s.n. RB21916 (2.1); Meireles, J.E.: 555 (2.5), 556 (2.2); Mezabarba, V.P.: 41 (2.2), 42 (2.5); Moreira, C.: s.n. R92972 (3.4); Nicolau, S.A.: 230 (1.2); Ochioni, P.: 129 (2.5), s.n. RB16435 (2.3); Oliveira, F.: 416 (2.5), 418 (3.1); Pabst, G.: 8914 (2.2); Pereira, A.B.: 31 (2.2); Pereira, E.: $34 B$ (2.5), 40B (2.3), 5677 (2.5), 5769 (2.5), 7051 (3.3), 7055 (2.5), 7124 (2.5); Peres, B.C.: 59 (2.5); Pilger, R.K.F.: 25 (3.3), 46 (2.3), s.n. RB25440 (1.3); Pinischi, R.B.: 37 (2.5); Porto, C.: 155 (1.2), 156 (2.3), 157 (3.3), 159 (2.2), 167 (2.5), 172 (2.3), 174 (3.1), 182 (2.3), $826(1.1), 1848(2.2)$; 2738 (2.3); Quinet, A.: 249 (2.2); Ribeiro, R.: 443 (2.3); Sampaio, A.: 4736 (2.5), 4738 (2.2), 4804 (1.2); Scheinvar, L.: 65 (2.5); Schettino, V.M.: 167 (2.2); Schwacke, P.: 12131 (3.4); Segadas-Vianna, F.: 5173 (3.1); Silva, M.: 18 (2.5); Silva Neto, S.J.: 834 (1.2), 835 (2.5), 1180 (1.2); Silvestre, L.: 58 (3.1), 65 (2.5); Strang H.: 171 (1.2), 622 (3.1), 735 (3.1), 740 (1.2), 803 (3.3), 849 (2.5), 931 (2.2); Sucre, D.: 5146 (2.5), 5197 (2.5); Toledo, F.T.: 728 (2.2), 6406 (2.3), 6409 (2.2); Ule, E.: 56 (3.4), 68 (2.3), 81 (3.3), 187 (2.1), 188 (1.2), 614 (1.3), 615 (2.2); Vianna, M.C.: 184 (1.2), 185 (2.5); Vital, D.M.: 4864 (3.1); Weddell, H.A.: 1555 (2.4). 